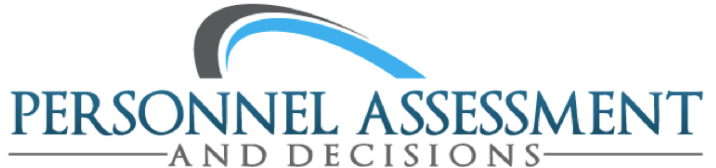

Personnel Assessment and A N D D E C I S I N S

Decisions

Volume 5

Issue 2 Reducing Discrimination in the

Workplace

Article 4

2019

\title{
A Review of Compensatory Strategies to Mitigate Bias
}

\author{
Oscar Holmes IV \\ Rutgers University - Camden \\ Gabrielle Lopiano \\ Emory University \\ Erika V. Hall \\ Emory University
}

Follow this and additional works at: https://scholarworks.bgsu.edu/pad

Part of the Human Resources Management Commons, Industrial and Organizational Psychology Commons, Organizational Behavior and Theory Commons, and the Other Psychology Commons How does access to this work benefit you? Let us know!

\section{Recommended Citation}

Holmes, Oscar IV; Lopiano, Gabrielle; and Hall, Erika V. (2019) "A Review of Compensatory Strategies to Mitigate Bias," Personnel Assessment and Decisions: Number 5 : Iss. 2 , Article 4.

DOI: https://doi.org/10.25035/pad.2019.02.004

Available at: https://scholarworks.bgsu.edu/pad/vol5/iss2/4

This Main Article is brought to you for free and open access by the Journals at ScholarWorks@BGSU. It has been accepted for inclusion in Personnel Assessment and Decisions by an authorized editor of ScholarWorks@BGSU. 


\title{
A Review of Compensatory Strategies to Mitigate BIAS
}

\author{
Oscar Holmes IV', Gabrielle Lopiano ${ }^{2}$, and Erika V. Hall ${ }^{2}$
}

\author{
1. Rutgers University - Camden \\ 2. Emory University
}

\section{KEYWORDS}

social category label, LGBTQ, race, compensatory strategy, impression management, bias
ABSTRACT

Experiences of bias and discrimination remain pernicious obstacles for many individuals. Both micro- and macro-level interventions are necessary to eliminate and/or mitigate these negative experiences. This review focuses on micro-level interventions, specifically, five types of compensatory strategies that targets can use to eliminate and/or mitigate the bias and discrimination they experience. In this manuscript, we synthesize the research on humor, avoidance, affiliation, enhancement, and social category label switching strategies; describe identities with which the strategies could be used; and highlight strengths and weaknesses of each of the strategies. Finally, we propose actionable directions for future research for each of the compensatory strategies.
Research shows that employee discrimination remains an intractable organizational issue (Avery, Volpone, \& Holmes, 2018; Cortina, Kabat-Farr, Leskinen, Huerta, \& Magley, 2013). For example, in 2017, 84,254 charges of discrimination were filed with the Equal Employment Opportunity Commission (EEOC) - nearly 4,000 more the number of charges that were filed with the office in 1997 (U.S. Equal Employment Opportunity Commision, 2017). Although the EEOC champions macrolevel interventions to combat discrimination, people with marginalized identities are often compelled to engage in various compensatory strategies-defined as micro-level identity management tactics that attempt to mitigate bias and discrimination due to one's social identities (e.g., Miller \& Kaiser, 2001; Miller, Rothblum, Felicio, \& Brand, 1995; Shelton, Richeson, \& Salvatore, 2005; Singletary \& Hebl, 2009).

In their review of four compensatory strategies, Ruggs, Martinez, and Hebl (2011) found that acknowledging one's readily observable stigma (e.g., race, physical disability), disclosing one's invisible stigma (e.g., sexual orientation, prison record), increasing the positivity and friendliness toward others (e.g., smiling more), and providing individuating information beyond the stereotypes about one's group (e.g., a gay male indicating that he has served in the military) all had varying degrees of effectiveness in mitigating interpersonal discrimination. This review was a welcomed first step in integrating important findings surrounding the efficacy of compensatory strategies. The challenge remains that individuals can and do enact several additional compensatory strategies with little understanding or empirical guidance as to the likely function and effectiveness of those strategies (see Table 1). Thus, additional reviews of research are needed, particularly considering the pernicious and widespread negative outcomes that bias and discrimination have on societies, organizations, teams, and individuals. For example, bias and discrimination have been linked to reduced job satisfaction, organizational commitment, and job performance (Ensher, Grant-Vallone, \& Donaldson, 2001; Jones, Peddie, Gilrane, King, \& Gray, 2016; Madera, King, \& Hebl, 2012), and increased stress, identity threat, turnover intentions, and incivility (Avery, McKay, Wilson, \& Tonidandel, 2007; Holmes, Whitman, Campbell, \& Johnson, 2016; McKay et al., 2007; Rabelo \& Cortina, 2013).

Although the onus of eradicating bias and discrimination should not be placed on the targets, considering their negative outcomes, this research services individuals who seek evidence-based solutions to mitigate or eliminate individual instances of bias and discrimination. Further-

\footnotetext{
Corresponding author:

Oscar Holmes IV

227 Penn Street, Camden, NJ 08102

Email: Oscar.HolmesIV@rutgers.edu
} 
TABLE 1.

Overview of Compensatory Strategies, Their Function, and Examples

\begin{tabular}{lll}
\hline Compensatory strategy & Function & Example of practical use to mitigate bias \\
\hline Social category label & $\begin{array}{l}\text { Recognizes that synonymous labels } \\
\text { can activate different stereotypes. Thus, } \\
\text { people can strategically choose the more } \\
\text { positively valanced label to mitigate bias. }\end{array}$ & $\begin{array}{l}\text { As (an African American vs. a Black) woman, you } \\
\text { should hire me because I can add unique insights to } \\
\text { this organization. }\end{array}$ \\
& $\begin{array}{ll}\text { (Gay/lesbian vs. homosexual) people should have } \\
\text { the right to adopt children. }\end{array}$ \\
& $\begin{array}{l}\text { I was so excited when my (partner vs. boyfriend) } \\
\text { told me about this job opening, I have always } \\
\text { wanted to work for this company. }\end{array}$ \\
\hline Humor & $\begin{array}{l}\text { Attempts to mitigate bias and put people } \\
\text { at ease by bringing levity to potentially } \\
\text { tense racial interactions. }\end{array}$ & $\begin{array}{l}\text { Of course, me-the Black guy-would be the only } \\
\text { one late to our team meeting! }\end{array}$ \\
\hline $\begin{array}{l}\text { Attempts to avoid or minimize } \\
\text { one's connection with or interest } \\
\text { in a stigmatized identity to thwart } \\
\text { categorization. }\end{array}$ & $\begin{array}{l}\text { White supervisor: Do you think our organization is } \\
\text { sufficiently diverse? }\end{array}$ \\
& $\begin{array}{l}\text { Hispanic subordinate: I do not spend much time } \\
\text { thinking about that. I think we should just hire the } \\
\text { best people for the job. }\end{array}$ \\
\hline $\begin{array}{l}\text { Highlights the positive aspects of } \\
\text { and advocates for an identity to shift } \\
\text { viewpoints, improve outcomes, and } \\
\text { mitigate bias. }\end{array}$ & $\begin{array}{l}\text { Native American employee: Considering the history } \\
\text { of racism in this country, I think it is necessary } \\
\text { that our organization adopt a robust affirmative } \\
\text { action policy as research consistently highlights the } \\
\text { discrimination that racio-ethnic minorities face in } \\
\text { the job market. }\end{array}$ \\
\hline $\begin{array}{l}\text { Highlights commonalities with others } \\
\text { to reinforce a superordinate identity that } \\
\text { connects interaction partners to mitigate } \\
\text { bias. }\end{array}$ & $\begin{array}{l}\text { I see that you are a Rutgers alum. As my résumé } \\
\text { indicates, I also graduated from there and thoroughly } \\
\text { enjoyed it. Where did you stay when you were } \\
\text { there? --Asian applicant in a job interview with a } \\
\text { White interviewer. }\end{array}$ \\
\hline
\end{tabular}

more, although overt discrimination has declined in recent decades (Dovidio \& Gaertner, 1986; McConahay, 1983; Swim, Aikin, Hall, \& Hunter, 1995), interpersonal discrimination (i.e., microaggressions, shortened interaction length, decreased eye contact) has persisted (Hebl, Foster, Mannix, \& Dovidio, 2002; King \& Ahmad, 2010; Ruggs et al., 2011). Because these subtler forms of discrimination are often difficult to detect and enact policy to mitigate, it is important to identify the effectiveness of compensatory strategies that targets might use. In the current manuscript, we further this literature by (a) synthesizing the findings of five compensatory strategies (e.g., humor, avoidance, enhancement, affiliation, and social category label switching), (b) offering examples of identities with which the strategies could be effective, (c) highlighting strengths and weaknesses of each of the strategies, and (d) offering possible direc- tions for future research (see Figure 1). We focus on these five compensatory strategies because of their ease of use, broad applicability to multiple identities, and because they have yet to be integrated in a previous review.

\section{Humor as a Compensatory Strategy}

Smith, Harrington, and Neck (2000) defined humor as any form of communication (e.g., joke, wit, pun, sarcasm, nonverbal body language, etc.) that is intended to evoke amusement or laughter. Martin, Puhlik-Doris, Larsen, Gray, and Weir (2003) identified four types of humor: affiliative, self-enhancing, aggressive, and self-defeating. They explained that affiliative humor attempts to "enhance one's relationship with others in a way that is relatively benign and self-accepting," whereas self-defeating humor is "done at the expense and detriment of the self," which occurs when 
FIGURE 1.

Compensatory Strategy Theoretical Model

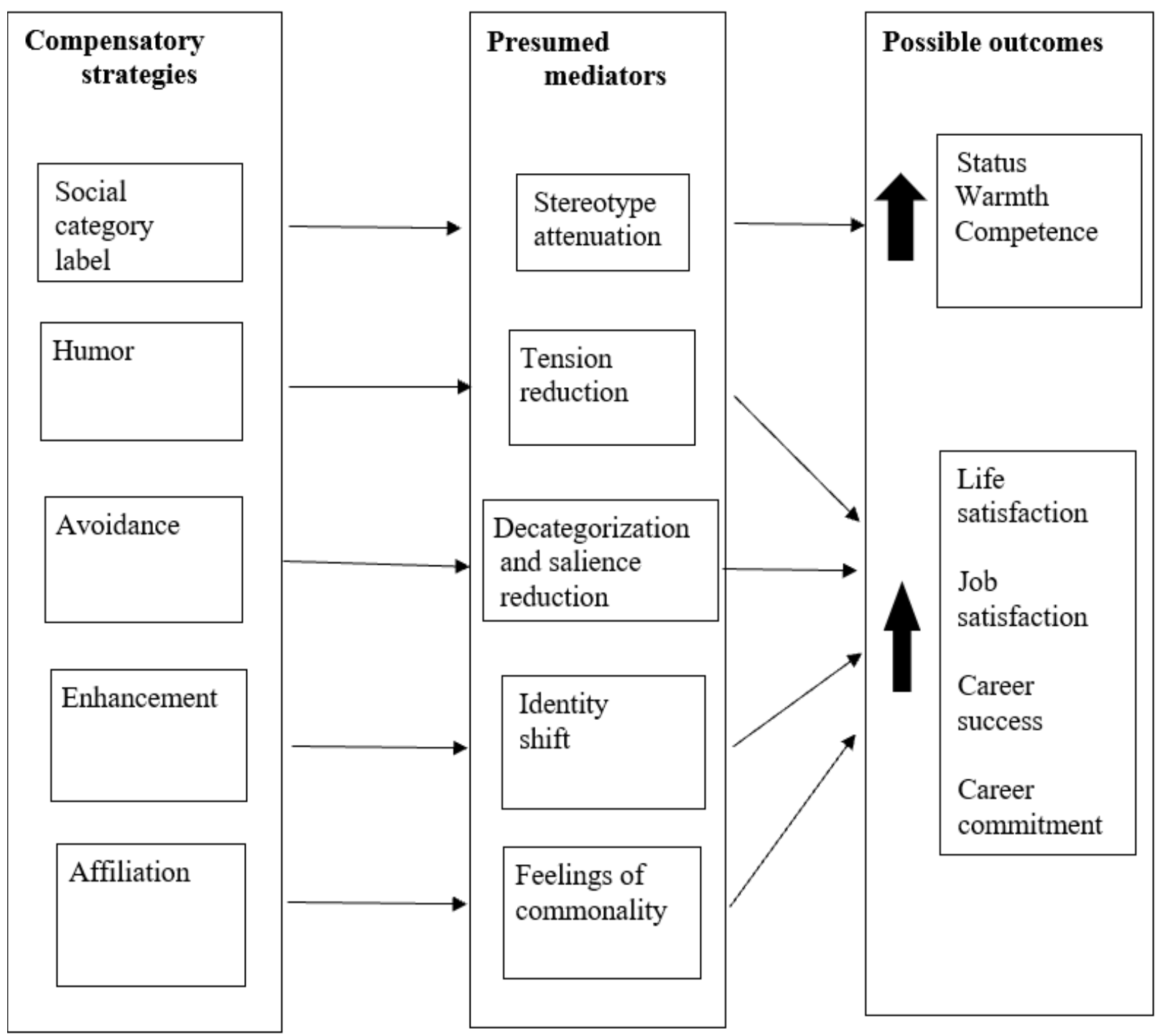

one engages in excessive self-deprecating jokes, situations, or activities (Martin et al., 2003, p. 52; italics in original). In contrast, self-enhancing humor attempts to improve one's relative standing over others but in a way that is "tolerant and non-detrimental to others" whereas aggressive humor does it in a way that is "hostile or denigrating towards others" (Martin et al., 2003, p. 52). Considering the multiple ways humor can facilitate relationship building with others, it is unsurprising that employees often use humor in organizations and empirical research supports this use (MacHovec, 1988). Although they issued the appropriate caveats (i.e., warnings against derogatory humor, etc.), Mesmer-Magnus, Glew, and Viswesvaran (2012) found in their meta-analysis that employee and supervisor use of humor in the workplace was positively related to performance, satisfaction, cohesion, and well-being, and negatively related to burnout, stress, and withdrawal behaviors. Because relationship maintenance and impression management are common interpersonal goals (Bolino \& Turnley, 2003), the strategic use of humor has been documented across a broad range of identities such as racio-ethnic, disability, obesity, pregnancy, gender, sexual orientation, marital status, and religion to achieve these goals (Anesi, 2018; Bingham \& Green, 2016; Puhl \& Brownell, 2006; Roberts, Cha, \& Kim, 2014). Next, we highlight some examples of how individuals might use humor. 
In an effort to avoid the negative stereotypes of being lazy and less competent, an obese employee might use humor by volunteering to travel to an important client and stating, "I can close that account, but just make sure the secretary books me an aisle seat in economy plus and rents me a full-size car this time. The last time I traveled, I almost suffocated sitting in that basic coach window seat and that tiny economy car rental!" Additional research has revealed that disabled people often strategically employ humor to make people comfortable with their disability and to curtail the bias and discrimination they might experience (Anesi, 2018; Bingham \& Green, 2016). Despite the gratuitous nature of the information, in her TED talk, Sheena Iyengar, who is blind, evoked laughter from her audience when she told them to raise their hands in response to her questions only if they wanted to burn off calories. As a final example of the humor strategy, imagine the stereotype-confirming situation when a Black employee arrives late again to his staff meeting. To break the tension, he jokingly states, "You know Black people are always on CP [colored people] time-it's cultural!" and the room erupts in laughter as he takes his seat. As we have demonstrated that there is a wide array of ways in which humor can be employed colloquially, we now turn to a discussion of how it has been discussed in prior academic literature.

Some studies have found gender, racial, and sexual identity differences in the use of humor. For example, Puhl and Brownell (2006) found that $79 \%$ of women and $91 \%$ of men in their study used humor to cope with the stigma of obesity when interacting with others. Hay (2000) found that women employed humor to initiate or maintain in-group solidarity almost two times as often as men. In their study, Smith et al. (2000) found no gender differences but that people were more likely to use humor to resolve conflict if they were similar in race and seniority as their interaction partners. Likely due to concerns of their not being taken seriously, African Americans were least likely to use humor to resolve conflicts whereas Asian and Hispanic Americans used humor at slightly lower rates than White Americans (Smith et al., 2000). In an effort to understand whether gender impacted the effects that humor has on outcomes, Evans, Slaughter, Ellis, and Rivin (2019) found in their experimental study that using humor increased men's, but decreased women's, status, performance, and leadership ratings in comparison with their same-gender counterparts. While studying Black medical school students, Roberts and colleagues (2014) found that those who employed racial humor strategies experienced lower levels of depression and intentions to quit medical school and higher levels of medical career commitment. Willard (2010) found that 70\% of LGBTQ people thought humor was an effective way to come out, decrease anxieties, raise awareness, and provide support. Interestingly, the participants reported using humor at work (more than any other location) to deal with hetero- sexism (Willard, 2010). Furthermore, Willard reported that LGBTQ people used humor, oftentimes as come backs or to de-escalate a potentially dangerous situation; that transgender people used humor more often than gay, lesbian, bisexual, or queer people; and that younger LGBTQ people used humor more often than older LGBTQ people.

If individuals decide to use humor, they should include their interaction partner in on the humor as much as possible. In her study, Bing (2004, p. 28) found that inclusive humor defined as "humor that makes fun of absurd attitudes, ideas, beliefs, and systems" that keep one group subordinate to others was ultimately more effective than divisive humor (e.g., humor that attacks others) because it highlights problems but still facilitates the amusement of both in-group and out-group members. Across several experimental studies, Bitterly, Brooks, and Schweitzer (2017) found that although people rated those who used humor (regardless of whether it was appropriate or successful) as more confident than those who did not, people only benefitted (e.g., increased status, competence, and likelihood of being selected as a leader) when their jokes were appropriate and successful (e.g., resulted in laughter). Telling inappropriate jokes actually reduced status and competence ratings, although if they still elicited laughter from others this penalty was reduced (Bitterly et al., 2017).

A strength of using humor as a compensatory strategy is that it can be especially helpful in diffusing tense, awkward, or stressful identity-based situations in a nonthreatening manner that protects the relationship between the target of bias and his/her interaction partner (Ashforth, Kreiner, Clark, \& Fugate, 2007). Another strength is that it can put people at ease with the identity in question by signaling that the target is not that "serious" or "uptight" about their identity group or the evoked identity threat (Holmes et al., 2016; Roberts, Cha, \& Kim, 2014).

Despite its broad use and appeal, a drawback of enacting humor is that it can be risky (Malone, 1980). As a complex form of communication, humor requires the enactor to have some degree of comedic skill and some shared sensibilities and contextual understandings between the enactor and the audience in order to avoid harm (Malone, 1980; Romero \& Cruthirds, 2006; Smith et al., 2000). To this point, Willard's (2010) LGBTQ participants recognized that humor is not always appropriate to use, as nearly $23 \%$ thought that homophobia and heterosexism were offenses too serious to use humor and that using humor with these offenses could lead to more negative outcomes. In addition to the relational risks, employing humor can lead to other unintentional outcomes. For example, Coser (1960) found that the hierarchical power structure was still maintained when subordinates used humor to express aggression (i.e., masked hostility) toward their superiors to satisfy their own immediate psychological needs instead of challenging superiors to engage in any serious work to upend the status quo. 
More recently, Bing (2004) argued that humor can sustain the social hierarchy and reinforce the status quo as telling jokes can evoke stereotypical scripts and inherently signals status.

\section{Avoidance as a Compensatory Strategy}

Avoidance (sometimes referred to as social distancing) is another compensatory strategy that people can employ to preempt or mitigate bias and discrimination (Cooper \& Jones, 1969). This strategy entails people intentionally engaging in behaviors that reduce the salience of their stigmatized identities by evading, to the extent possible, conversations, activities, and appearances related to their identities (Roberts et al., 2014). Like humor, avoidance can be employed by people from a variety of different identity groups (e.g., racio-ethnic, religion, gender, sexual orientation, obesity, disability, etc.). For example, a gay employee who walks in on his coworkers casually conversing about their weekends might refrain from entering the conversation or proactively steer the conversation away from talking about significant others. This example references an avoidance strategy rather than a concealment strategy because, in our example, the gay employee is "out" to his colleagues, but he is simply uncomfortable or perceives that his coworkers might react negatively if he talks about his significant other. A Hispanic attorney who tries not to draw attention to her ethnicity and gender by choosing not to be involved with the mentoring programs for Hispanic and female junior associates at her firm is another example of using an avoidance strategy. Although neither of the individuals have to deny or conceal their identities in these examples, their decision to use an avoidance strategy can be rooted in their desire to maintain social harmony or not to have others categorize them around those identities (Arnett \& Sidanius, 2018).

In their meta-analysis, Suls and Fletcher (1985) found that avoidance generally allowed people to cope positively with stress in the short run, but if the stressor persisted, then attending to the stressor was a superior approach to take. Unsurprisingly, more recent research has found that avoidance leads to decreased relational satisfaction when the avoidance is long term, but satisfaction decrements are largely absent with short-term avoidance use (Dailey \& Palomares, 2004). These results are in line with a study that Roberts et al. (2014) conducted of Asian journalists that found that using an avoidance strategy lowered the journalists' perceived career success, an attitudinal outcome that takes into account one's long-term perceptions. However, an earlier study did not find long-term negative effects of using an avoidance strategy. In their study, Roberts, Settles, and Jellison (2008) found that although avoidance was not positively related to outcomes like depression, intention to quit, and medical career commitment, it did no harm to the medical students who used this strategy. Considering these mixed findings, it suggests that negative outcomes with long-term use of the avoidance strategy depends on the context. For example, there is evidence that obese people, particularly women, use an avoidance strategy (e.g., not going to a gym or using a trainer, etc.) to mitigate bias they perceive they will encounter despite the fact that physical exercise might reduce their stigmatization in the long run (Packer, 1989). In this case, the obese person might successfully thwart short-term bias by avoiding those activities that would make her weight even more salient. However, she could also hurt herself in the long run by avoiding physical activities that could improve her health, mood, and well-being.

There is a body of work that supports the idea that people make (positive/negative) assumptions about individuals based on their associations with stigmatized others, which leads to (positive/negative) outcomes for the associated person (Goffman, 1963; Hall, Avery, McKay, Blot, \& Edwards, 2019; Hernandez et al., 2016; Sigelman, Howell, Cornell, Cutright, \& Dewey, 1991; Swim, Ferguson, \& Hyers, 1999). One of the strengths of stigmatized people using an avoidance strategy is that they can facilitate acceptance and relationship building with others, particularly among biased people or those who have stigma-by-association concerns (Creary, Caza, \& Roberts, 2015; Swim et al., 1999). Another strength is that inauthentic feelings and cognitive resource depletion is reduced when one uses an avoidance rather than concealment strategy because the former does not require the individual to hide his/her identity (Roberts \& Creary, 2013). A final strength of the avoidance strategy is that it can often be used without others' knowledge, thus reducing the chances of backlash from interaction partners (Dailey \& Palomares, 2004).

One of the drawbacks of using an avoidance strategy is that in their effort to eschew categorization, people might forgo identity-based opportunities that could benefit them personally and professionally. For example, Women in STEAM, The PhD Project, the National Association of Black Accountants, the Hispanic Bar Association, and Asian American Journalist Associations are just a few organizations whose mission it is to provide professional development opportunities, mentoring, and support to members of specific identity groups. Although this type of avoidance might mitigate bias from out-group members, another drawback is that it could foster resentment, mistrust, and exclusion from in-group members (Butler, 1991; Wyatt \& Silvester, 2015). A final drawback with the avoidance strategy is that individuals might subsequently learn that their acceptance by and relationships with others were only superficial, which could lead to their feeling betrayed, used, and embarrassed (Holmes et al., 2016; Petriglieri, 2011).

\section{Enhancement as a Compensatory Strategy}

Similar to the previous two strategies, any stigmatized 
identity group member may use an enhancement compensatory strategy to mitigate bias. According to Roberts et al. (2014, p. 530), enhancement "involves attempts to create more positive meanings around one's [identity] group through publicly embracing the identity, educating others about the positive attributes of the identity, and advocating on behalf of the group" (see also Bell \& Nkomo, 2001; Thomas, 1993). Consequently, individuals who employ enhancement strategies seek to provide their counterparts with a view of the social identity that is more comprehensive than what can be gleaned from stigmatizing societal stereotypes. For example, when a Black advertising executive receives push back during her pitch for her organization to create a Black History Month themed advertisement, she reminds her colleagues of the invaluable contributions that Black people have made to the country and argue that such an ad would send a powerful message of valuing diversity and inclusion not only to their clients but also to employees like herself in the firm. As another example, a transgender employee might persuade her company to adopt a policy that requires employees to add their desired pronouns in their email signatures to respect people's preferred gender identity and normalize the acceptance of nonbinary and transgender identities in the workplace.

Perhaps, the most public display in recent history of a high-profile person employing enhancement strategies occurred in the Obama administration. President Obama experienced swift negative backlash from many White Americans, yet ardent support from many African Americans and other racio-ethnic minorities, when he made a statement on racial profiling (e.g., enhancement strategy) in support of the eminent African American Harvard professor, Henry Louis Gates, Jr., who was arrested on the suspicion that he was breaking into his own Cambridge home (Price, 2016; Staff Reports, 2016). Just 6 months into his presidency, his first public use of an enhancement tactic, according to a Washington Post article, left "the lasting impression that the president had stepped into a divisive racial debate for which he was unprepared" and his "image as a racial healer never recovered" (Staff Reports, 2016). Obama was again met with mixed racio-ethnic support when he used an enhancement strategy while opining on Trayvon Martin's murder stating, "When I think about this boy, I think about my own kids. If I had a son, he'd look like Trayvon" (Thernstrom, 2013). Like other compensatory strategies, these examples highlight that depending on one's perspective and relationship with the enactor, the use of enhancement strategies can be met with both positive and negative outcomes simultaneously. Other research has found that some people use enhancement strategies to take advantage of positive stereotypes. For example, Oyserman and Sakamoto (1997) has found that some Asian Americans emphasize their competence to fit the "model minority" expectations that others have of them to thwart bias and advance professionally.
Alternatively, to mitigate the bias they experience, some women incorporate conventionally feminine attributes into their masculine professional identities (Ely, 1995). Finally, in another study surveying Asian journalists, Roberts and colleagues (2014) found that enhancement was positively related to self-rated perceptions of career success but only when racial centrality was low. In the next sections, we examine strengths and weaknesses of this strategy.

Enhancement strategies may yield several downstream advantages. First, using an enhancement strategy may increase feelings of authenticity and pride in one's self and others because enactors proactively defend their or others' identities against threats and advocate on their own or others' behalf. In turn, authenticity is associated with several positive psychological outcomes including increased subjective well-being (Kifer, Heller, Perunovic, \& Galinsky, 2013), self-esteem (Kernis \& Goldman, 2006), and positive affect (Gino, Kouchaki, \& Galinsky, 2015). Another strength is that counterparts typically feel closer and more intimate with individuals who disclose personal information about their "true" selves (Phillips, Rothbard, \& Dumas, 2009; Roberts, 2005), so enhancement strategies that emphasize stigmatized social identities may help individuals form bonds with nonstigmatized coworkers in organizations. A final strength of using enhancement strategies is that they can also lead to positive macrolevel outcomes. In their groundbreaking study exploring how cultural diversity impacted work group functioning in three different professional services firms, Ely and Thomas (2001) found that although each diversity perspective led firms to increase their workforce diversity, only the integration-and-learning perspective achieved sustained positive changes to the work groups' processes, innovation, and productivity.

Enhancement strategies may also yield several downstream disadvantages. For example, although nonstigmatized individuals may be more positive and politically correct around individuals who emphasize a stigmatized identity (Barron, Hebl, \& King, 2011), they may privately hold negative thoughts about these individuals and be frustrated about their inability to publicly express them (Apfelbaum, Sommers, \& Norton, 2008; Trawalter, Adam, Chase-Lansdale, \& Richeson, 2012). Another drawback of using an enhancement strategy is that it can create overt backlash. In addition to the kind of backlash that President Obama experienced, research has also found that White Americans directed more prejudice toward strongly identified racio-ethnic minorities rather than their weakly identified counterparts (Kaiser \& Pratt-Hyatt, 2009). A final drawback of the enhancement strategy is that individuals who are too preoccupied with proving the positive aspects associated with their stigmatized identity might become cognitively taxed from this preoccupation, and their performance may ultimately suffer on workplace tasks (Steele, 1997). 


\section{Affiliation as a Compensatory Strategy}

Because strong professional bonds serve as foundations of social capital and networks that can facilitate career advancement (Ibarra, 1995), individuals may mitigate bias by attempting to affiliate with nonstigmatized others or other superordinate identities. Like the aforementioned strategies, any social identity member can use an affiliation strategy. Affiliation entails individuals' attempts to highlight commonalities with others to elevate the salience of their common identities (Roberts et al., 2014). These efforts can involve focusing conversations on shared interests and experiences with others. For example, an employee who is one of few Muslims in an office might frequently evoke her departmental identity and values or talk about her affinity for the local professional athletic teams when conversing with her colleagues. A gay employee with children might choose to affiliate with coworkers based on their shared parental identity and a Hispanic employee might often reference his alma mater that he shares with many of his office colleagues. Because people are made up of multiple identities, affiliation allows people to strategically draw on their other identities as needed to eschew bias (Shih, Young, \& Bucher, 2013).

It seems the importance of one's identity influences the frequency with which one uses an affiliation strategy. Roberts and colleagues (2014) found that people were most likely to use affiliation in employment settings when their racial identity centrality was low, and their professional identity centrality was high. Despite its putative benefit to create greater cohesion with others, interestingly, affiliation was not related to employees' job satisfaction, life satisfaction, or perceived career success (Roberts et al., 2014). Additional research suggests that employees who opt to frequently use an affiliation strategy might perceive themselves to be the target of discrimination less often than those who opt to maintain the salience of their own stigmatized identities (Chattopadhyay, Tluchowska, \& George, 2004; Major et al., 2002). It is important to note that this research does not argue that they objectively experience less discrimination but rather their status justifying beliefs allow them to more easily miss, discount, or rationalize away experiences and interactions that others might interpret as bias or discrimination (Major et al., 2002). Ironically, high status individuals also enact affiliation strategies to mitigate bias. Across five studies, Arnett and Sidanius (2018) found that people who attended elite universities opted to conceal this information in favor of affiliating on an identity of similar status (e.g., hometown, major, etc.) when they interacted with someone who attended a lower status university in order to maintain social harmony.

Research has long established that finding commonality with others increases interpersonal liking and influence (Cialdini \& Goldstein, 2004), thus using an affiliation strategy has several strengths. First, building strong interper- sonal relationships with colleagues satisfies belongingness needs, which should, in turn, put stigmatized individuals at ease and enhance their well-being and motivation at work (Heaphy \& Dutton, 2008). Second, individuals who choose an affiliation strategy typically have more direct contact with outgroup members, which can be an effective means to reduce bias and improve attitudes toward their stigmatized group as a whole (Allport, 1954; Pettigrew \& Tropp, 2006). Finally, focusing on similarities and a common superordinate identity may improve perceptions of "fit" between interaction partners in professional settings, which may be particularly valuable in careers where certain groups are severely underrepresented (e.g., women, African Americans, Hispanics in STEM fields, etc.).

Despite these strengths, there are also drawbacks of using an affiliation strategy. Similar to the other strategies, affiliation may involve acculturating to the dominant group, and such efforts can lead to feelings of inauthenticity, which has been linked to adverse psychological outcomes (Gino et al., 2015). Additionally, affiliation efforts may lead disadvantaged group members to perceive less inequity than is actually present and subsequently withdraw their efforts to combat bias and discrimination (Dovidio, Gaertner, Ufkes, Saguy, \& Pearson, 2016; Saguy, Tausch, Dovidio, \& Pratto, 2009). Last, persistent attempts to affiliate might ultimately reduce task performance if individuals avoid drawing upon their diverse identities and experiences to innovate, solve complex problems, or enter new markets or partnerships (Ely \& Thomas, 2001; Roberson, Holmes, \& Perry, 2017).

\section{Social Category Label Switching as a Compensatory Strategy}

Unlike the previously reviewed strategies that can be employed by a broad range of social identity group members, social category label (SCL) switching is only applicable to social identities that have synonymous labels (e.g., Black vs. African American, gay vs. homosexual, etc.). For example, an entrepreneur pitching her new startup to investors might choose to say, "it is the first African American-owned" rather than "first Black-owned." A client in a retail store who needs to find the right dress for an important gala might ponder several options before asking the store clerk, "Because I'm overweight, would these dresses work for me?" instead of "Because I'm fat, would these dresses work for me?" As a final example, an attorney introducing her husband to her firm's partners might say, "he's an administrative assistant" rather than "he's a secretary" when asked what he does. Despite the fact that social identity labels can be interchangeable, SCL switching can mitigate bias because research has revealed that stereotypes that are associated with synonymous labels can vary in significant ways (Crawford, Brandt, Inbar, \& Mallinas, 2015; Hall, Phillips, \& Townsend, 2015; Rios, 2013; Smith, Murib, Motta, Callaghan, \& Theys, 2017). Because the labels 
sound differently, they can activate different stereotypes, which could lead to different attributions (Koch, Luft, \& Kruse, 2005; Vakoch \& Wurm, 1997; Wurm \& Vakoch, 1996). This simple strategic interchange may suppress stereotype activation and application among people enough to favorably impact the strategy user, or at least mitigate unfavorable reactions. This is important considering research confirms that even unconscious biased thoughts and stereotypes can influence individuals to make biased and discriminatory decisions (Kunda \& Spencer, 2003; Segrest Purkiss, Perrewé, Gillespie, Mayes, \& Ferris, 2006).

Although SCL switching is widely used, less is known about its effectiveness as a compensatory strategy. Fairchild (1985) found that White respondents ascribed the traits loud, lazy, and rude more often to "Blacks" than "Afro Americans." More recently, Hall and colleagues (2015) found that the label "Black" contained lower status, positivity, competence, and warmth perceptions than the label "African American," which ultimately led Whites to view a criminal suspect more negatively when he was identified as Black rather than African American. In fact, Hall and colleagues' research also found that U.S. newspaper articles that described suspects as Black had a more negative (specifically angry) emotional tone than when suspects were described as African American.

The SCL effect has also been studied in relation to sexual orientation (e.g., homosexual, gay, lesbian, etc.). Similar to racio-ethnic labels, these terms have also risen and fallen in preference over time (Herek, 1998). In testing the SCL effect, Rios (2013) found that right wing authoritarians (RWAs) reduced their anti-gay attitudes when they were presented with the label "gay men and lesbians" rather than "homosexuals." Yet, across 23 studies, Crawford et al. (2015) failed to replicate these findings and in two cases found significant results in the opposite direction, thus concluding that RWAs responded equally to the two labels. Lending some support to Rios' original findings, Smith and colleagues (2017) tested a three-way interaction among right wing authoritarianism, born again status, and social category label, and found that people were more often opposed to policy questions on the American National Election Study (ANES) when they were labeled as homosexual policies versus gay and lesbian policies. Finally, extending the SCL effect to the context of synonymous gay romantic labels (introducing a romantic partner as one's "boyfriend" vs. one's "partner"), we found limited support for the SCL effect across several of our own unpublished studies. Although two studies showed that the partner label was viewed more positively in terms of warmth and competence judgments when respondents' social dominance orientation was taken into account, the remaining nine studies either found no significant differences between the labels or were in the opposite direction we hypothesized (i.e., boyfriend was favored over partner). ${ }^{1}$ Taken together, these studies suggest that although the SCL effect is more straightforward with racio-ethnic SCLs, its effect is more complex when it comes to sexual orientation SCLs considering how they interact with certain individual difference variables.

Research shows people respond more negatively to others when they perceive others are attempting to strategically manipulate them (Bolino, Long, \& Turnley, 2015; Whitson, Wang, Kim, Cao, \& Scrimpshire, 2015). A strength of SCL switching is the facility of its use and its ability to often go undetected as a compensatory strategy. Ironically, its facility and ability to go undetected are also drawbacks of SCL switching. This is the case because people can also strategically employ SCL switching to increase the negative stereotypes that might be actived when they reference others. For example, knowing that the Black SCL evokes more criminality stereotypes than the African American SCL, police officers, prosecutors, and journalists with malevolent intentions can opt for the former label to influence others' perceptions of suspects. Another drawback of SCL switching is that the need to be aware of which label to use can increase cognitive stress beyond the existing stress associated with expectations of bias and discrimination. Furthermore, the SCL that mitigates discrimination might not be the most accurate or preferred label by the targets of discrimination, which could increase their feelings of inauthenticity and identity threat (Holmes et al., 2016). For example, although U.S.-born African Americans are also Black, technically, non-U.S.-born Blacks are not African Americans (e.g., Haitians, Nigerians, Dominicans, etc.). In the next section, we highlight directions for future research for these five compensatory strategies.

\section{Future Research Directions}

As the case with many studies, the compensatory strategy research can benefit from including longitudinal study designs in order to examine specifically how strategies are linked to long-term outcomes. For example, although President Obama experienced swift backlash when he used an enhancement strategy, he was still able to gain enough White voter support to win re-election in 2012. So, although it is evident that there are proximal outcomes with compensatory strategies, theory and empirical research are limited in explaining time horizon outcome effects of compensatory strategies. Situational judgment tests and daily diary method designs would also be a welcomed addition to the compensatory strategy literature. Considering the mixed findings across the literature, variety of study designs employed (e.g., experimental, field, etc.), and diversity of social identities involved, a meta-analysis would be helpful to build theory and empirically test important main effects and moderators. In the same vein of calling for more com-

1 Data available from first author upon request. 
plex theorizing and study designs, future research should examine curvilinear effects with compensatory strategy use. Currently, this research is dominated by investigations of linear effects, but it is likely that there are critical inflection points. For example, using affiliation, humor, enhancement, and avoidance strategies might all be positive up to a certain point, then their continued use might become negative.

Additionally, future research should examine the effectiveness of specific constellations of compensatory strategy use. Currently, the strategies are often investigated in isolation; however, it is likely that individuals use multiple compensatory strategies simultaneously. Although some of these strategies are incongruent (e.g., enhancement and avoidance), others are quite complementary (e.g., affiliation, humor, and enhancement). Future research should also identify important moderators that affect the compensatory strategy-outcome relationship from the enactor and interaction partner perspective. For example, political skill and emotional intelligence are likely individual differences that greatly increase the efficacy of employing compensatory strategies, particularly riskier ones like humor and enhancement.

The mixed research findings suggest that SCL switching may be a more effective compensatory strategy within specific contexts (racio-ethnic labels rather than sexual orientation labels, etc.), yet the boundaries of its effectiveness are still unknown, thus presenting a ripe avenue for future research. First, researchers should clarify the ways in which contextual (e.g., work vs. nonwork) and individual difference moderators (e.g., RWA, SDO, etc.) influence the effects of different labels on perceptions of a group and the mechanisms through which they occur. Second, management research would benefit from an understanding of how the associated stereotype content embedded within different SCLs impact the career outcomes (e.g., hiring, promotion) and workplace interactions (e.g., cohesion, conflict) of targets and nontargets of discrimination. Finally, Galinsky et al. (2013) theorized a model of reappropriation, or "taking possession of a slur previously used exclusively by dominant groups to reinforce a stigmatized group's lesser status" (p. 2020) to challenge the negative associations of the label. Future research is needed to determine whether the frequency of more stigmatized SCL use is significantly related to decreases in the label's negative stereotypes content (e.g. frequently using Black in positive ways to abate its negative connotation). Finally, few researchers have investigated stereotype embeddedness as it relates to the SCL effect with other important social category groups. Investigating the SCL effect in other identity labels such as Hispanic/Latino/ $\mathrm{a} / \mathrm{x}$, Miss/Ms./Mrs., janitor/custodian, stripper/go-go dancer, illegal alien/undocumented immigrant, prostitute/escort would be informative in extending this literature and testing important boundary conditions.

\section{Conclusion}

The onus to eliminate bias and discrimination should not fall solely on the targets of bias and discrimination. Nonetheless, considering the negative impact that bias and discrimination exact on those who experience it, it is important that scholars investigate microlevel strategies to provide individuals with evidence-based conclusions of their efficacy. In this review, we synthesized the research on five compensatory strategies, provided examples of how they can be used to mitigate bias, highlighted their strengths and weaknesses, and proposed directions for future research. As other researchers have found (Ruggs et al., 2011), our review suggests that these compensatory strategies have the potential to reduce bias and discrimination.

\section{REFERENCES}

Allport, G. W. (1954). The nature of prejudice. New York, NY: Addison-Wesley.

Anesi, J. (2018). Laughing matters: Humour as advocacy in education for the disabled. Disability and Society, 33(5), 723-742. http://doi.org/10.1080/09687599.2018.1453782

Apfelbaum, E. P., Sommers, S. R., \& Norton, M. I. (2008). Seeing race and seeming racist? Evaluating strategic colorblindness in social interaction. Journal of Personality and Social Psychology, 95(4), 918-932. Retrieved from http://www. ncbi.nlm.nih.gov/pubmed/18808268

Arnett, R. D., \& Sidanius, J. (2018). Sacrificing status for social harmony: Concealing relatively high status identities from one's peers. Organizational Behavior and Human Decision Processes, 147, 108-126. http://doi.org/10.1016/j.obhdp.2018.05.009

Ashforth, B. E., Kreiner, G. E., Clark, M. A., \& Fugate, M. (2007). Normalizing dirty work: Managerial tactics for countering occupational taint. Academy of Management Journal, 50, 149-174.

Avery, D. R., McKay, P. F., Wilson, D. C., \& Tonidandel, S. (2007). Unequal attendance: The relationships between race, organizational diversity cues, and absenteeism. Personnel Psychology, 60(4), 875-902. http://doi.org/10.1111/j.17446570.2007.00094.x

Avery, D. R., Volpone, S. D., \& Holmes IV, O. (2018). Racial discrimination in organizations. In A. J. Colella \& E. B. King (Eds.), The Oxford handbook of workplace discrimination (pp. 89-109). New York, NY: Oxford University Press. http://doi. org/10.1093/oxfordhb/9780199363643.013.8

Barron, L. G., Hebl, M., \& King, E. B. (2011). Effects of manifest eth nic identification on employment discrimination. Cultural Diversity and Ethnic Minority Psychology, 17(1), 23-30.

Bell, E. L., \& Nkomo, S. (2001). Our separate ways: Black and White women and the struggle for professional identity. Boston, MA: Harvard Business School Press.

Bing, J. M. (2004). Is feminist humor an oxymoron? Women and Language, 27(1), 22-33. 
Bingham, S. C., \& Green, S. E. (2016). Aesthetic as analysis: Synthesizing theories of humor and disability through standup comedy. Humanity \& Society, 40(3), 278-305. http://doi. org/10.1177/0160597615621594

Bitterly, T. B., Brooks, A. W., \& Schweitzer, M. E. (2017). Risky business: When humor increases and decreases status. Journal of Personality and Social Psychology, 112(3), 431-455.

Bolino, M. C., Long, D., \& Turnley, W. (2015). Impression management in organizations: Critical questions, answers, and areas for future research. Annual Review of Organizational Psychology and Organizational Behavior, 3, 377-406. http:// doi.org/10.1146/annurev-orgpsych-041015-062337

Bolino, M. C., \& Turnley, W. H. (2003). More than one way to make an impression: Exploring profiles of impression management. Journal of Management, 24, 237-250.

Butler, J. K. (1991). Toward understanding and measuring conditions of trust: Evolution of a conditions of trust inventory. Journal of Management, 17(3), 643-663. http://doi. org/10.1177/014920639101700307

Chattopadhyay, P., Tluchowska, M., \& George, E. (2004). Identifying the ingroup : A closer look at the influence of demographic dissimilarity on employee social identity. Academy of Management Review, 29(2), 180-202.

Cialdini, R. B., \& Goldstein, N. J. (2004). Social influence: Compliance and conformity. Annual Review of Psychology, 55, 591-621. http://doi.org/10.1146/annurev. psych.55.090902.142015

Cooper, J., \& Jones, E. E. (1969). Opinion divergence as a strategy to avoid being miscast. Journal of Personality and Social Psychology, 13(1), 23-30. http://doi.org/10.1037/h0027987

Cortina, L. M., Kabat-Farr, D., Leskinen, E. A., Huerta, M., \& Magley, V. J. (2013). Selective incivility as modern discrimination in organizations: Evidence and impact. Journal of Management, 39(6), 1579-1605. http://doi. org/10.1177/0149206311418835

Coser, R. (1960). Laughter among colleagues. Psychiatry, 23, 81-95.

Crawford, J. T., Brandt, M. J., Inbar, Y., \& Mallinas, S. R. (2015). Right-wing authoritarianism predicts prejudice equally toward "gay men and lesbians" and "homosexuals." Journal of Personality and Social Psychology, (MAY), 1-15. http://doi. org/10.1037/pspp0000070

Creary, S., Caza, B. B., \& Roberts, L. M. (2015). Out of the box? How managing a subordinate's multiple identities affects the quality of a manager-subordinate relationship. Academy of Management Review, 40(4), 538-562. http://doi. org/10.5465/amr.2013.0101

Dailey, R. M., \& Palomares, N. A. (2004). Strategic topic avoidance: An investigation of topic avoidance frequency, strategies used, and relational correlates. Communication Monographs, 71(4), 471-496. http://doi. org/10.1080/0363452042000307443

Dovidio, J. F., \& Gaertner, S. L. (1986). Prejudice, discrimination, and racism. Academic Press.

Dovidio, J. F., Gaertner, S. L., Ufkes, E. G., Saguy, T., \& Pearson, A. R. (2016). Included but Invisible? Subtle bias, common identity, and the darker side of "we." Social Issues and Policy Review, 10(1), 6-46. http://doi.org/10.1111/sipr.12017

Ely, R. J. (1995). The power of demography: Women's social con- struction of gender identity at work. Academy of Management Journal, 38(3), 589-634.

Ely, R. J., \& Thomas, D. A. (2001). Cultural diversity at work: The effects of diversity perspectives on work group processes and outcomes. Administrative Science Quarterly, 46(2), 229-273.

Ensher, E. A., Grant-Vallone, E. J., \& Donaldson, S. I. (2001). Effects of perceived discrimination on job satisfaction, organizational commitment, organizational citizenship behavior, and grievances. Human Resource Development Quarterly, 12(1), 53-72. http://doi.org/10.1002/1532-1096(200101/02) 12:1\%3C53::AID-HRDQ5\%3E3.3.CO;2-7

Evans, J. B., Slaughter, J. E., Ellis, A. P., \& Rivin, J. M. (2019). Gender and the evaluation of humor at work. Journal of Applied Psychology. http://doi.org/10.1037/apl0000395

Fairchild, H. H. (1985). Black, Negro, or Afro-American? The differences are crucial! Journal of Black Studies, 16(1), 47-55.

Galinsky, A. D., Wang, C. S., Whitson, J. A., Anicich, E. M., Hugenberg, K., \& Bodenhausen, G. V. (2013). The reappropriation of stigmatizing labels: The reciprocal relationship between power and self-labeling. Psychological Science, 24(10), 2020-2029. http://doi.org/10.1177/0956797613482943

Gino, F., Kouchaki, M., \& Galinsky, A. D. (2015). The moral virtue of authenticity: How inauthenticity produces feelings of immorality and impurity. Psychological Science, 26(7), 983996. http://doi.org/10.1177/0956797615575277

Goffman, E. (1963). Stigma: Notes on the management of spoiled identity. Englewood Cliffs, NJ: Prentice Hall.

Hall, E. V., Avery, D. R., McKay, P., Blot, J., \& Edwards, M. (2019). Composition and compensation: The moderating effect of individual and team performance on racial stigma-by-association and salary. Journal of Applied Psychology, 104(3), 448-463.

Hall, E. V., Phillips, K. W., \& Townsend, S. S. M. (2015). A rose by any other name? The consequences of subtyping "African-Americans" from "Blacks." Journal of Experimental Social Psychology, 56, 183-190. http://doi.org/10.1080/136443 6X.2014.960917

Hay, J. (2000). Functions of humor in the conversations of men and women. Journal of Pragmatics, 32, 709-742.

Heaphy, E. D., \& Dutton, J. E. (2008). Positive social interactions and the human body at work: Linking organizations and physiology. Academy of Management Review, 33(1), 137162.

Hebl, M. R., Foster, J. B., Mannix, L. M., \& Dovidio, J. F. (2002). Formal and interpersonal discrimination: A field study of bias toward homosexual applicants. Personality and Social Psychology Bulletin, 28, 815-825.

Herek, G. M. (1998). Stigma and sexual orientation: Understanding prejudice against lesbians, gay men and bisexuals. Thousand Oaks, CA: Sage Publications.

Hernandez, M., Avery, D. R., Tonidandel, S., Hebl, M. R., Smith, A. N., \& McKay, P. F. (2016). The role of proximal social contexts: Assessing stigma-by-association effects on leader appraisals. Journal of Applied Psychology, 101(1), 68-85.

Holmes IV, O., Whitman, M. V., Campbell, K. S., \& Johnson, D. E. (2016). Exploring the social identity threat response. Equality, Diversity and Inclusion: An International Journal, 35(3), 205-220. http://doi.org/10.1108/EDI-08-2015-0068 
Ibarra, H. (1995). Race, opportunity, and diversity of social circles in managerial networks. Academy of Management Journal, 38(3), 673-703. http://doi.org/10.2307/256742

Jones, K. P., Peddie, C. I., Gilrane, V. L., King, E. B., \& Gray, A. L. (2016). Not so subtle: A meta-analytic investigation of the correlates of subtle and overt discrimination. Journal of Management, 42(6), 1588-1613. http://doi. org/10.1177/0149206313506466

Kaiser, C. R., \& Pratt-Hyatt, J. S. (2009). Distributing prejudice unequally: Do Whites direct their prejudice toward strongly identified minorities? Journal of Personality and Social Psychology, 96, 432-445.

Kernis, M. H., \& Goldman, B. M. (2006). A multicomponent conceptualization of authenticity: Theory and research. Advances in Experimental Social Psychology, 38(6), 283-357. http://doi.org/10.1016/S0065-2601(06)38006-9

Kifer, Y., Heller, D., Perunovic, W. Q., \& Galinsky, A. D. (2013). The good life of the powerful: The experience of power and authenticity enhances subjective well-being. Psychological Science, 24(3), 280-288. http://doi. org/10.1177/0956797612450891

King, E. B., \& Ahmad, A. S. (2010). An experimental field study of interpersonal discrimination toward Muslim job applicants. Personnel Psychology, 63, 881-906.

Koch, S. C., Luft, R., \& Kruse, L. (2005). Women and leadership - 20 years later: A semantic connotation study. Social Science Information, 44(1), 9-39. http://doi. org/10.1177/0539018405050433

Kunda, Z., \& Spencer, S. J. (2003). When do stereotypes come to mind and when do they color judgment? A goal-based theoretical framework for stereotype activation and application. Psychological Bulletin, 129(4), 522-544.

MacHovec, F. J. (1988). Humor. Springfield, IL: Charles Thomas Publisher.

Madera, J. M., King, E. B., \& Hebl, M. R. (2012). Bringing social identity to work: The influence of manifestation and suppression on perceived discrimination, job satisfaction, and turnover intentions. Cultural Diversity and Ethnic Minority Psychology, 18(2), 165-170. http://doi.org/10.1037/ a0027724

Major, B., Gramzow, R. H., McCoy, S. K., Levin, S., Schmader, T., \& Sidanius, J. (2002). Perceiving personal discrimination: The role of group status and legitimizing ideology. Journal of Personality and Social Psychology, 82(3), 269-82. doi:10.1037/0022-3514.82.3.269

Malone, P. B. (1980). Humor: A double-edged tool for today's managers? Academy of Management Review, 5(3), 357-360.

Martin, R. A., Puhlik-Doris, P., Larsen, G., Gray, J., \& Weir, K. (2003). Individual differences in uses of humor and their relation to psychological well-being: Development of the humor styles questionnaire. Journal of Research in Personality, 37, 48-75. http://doi.org/10.1103/PhysRevA.32.3817

McConahay, J. B. (1983). Modern racism and modern discrimination: The effects of race, racial attitudes, and context on simulated hiring decisions. Personality and Social Psychology Bulletin, 9(4), 551-558.

McKay, P. F., Avery, D. R., Tonidandel, S., Morris, M. A., Hernandez, M., \& Hebl, M. R. (2007). Racial differences in employee retention: Are diversity climate perceptions the key? Person- nel Psychology, 60(1), 35-62.

Mesmer-Magnus, J., Glew, D. J., \& Viswesvaran, C. (2012). A meta-analysis of positive humor in the workplace. Journal of Managerial Psychology, 27(2), 155-190. doi: 10.1108/02683941211199554

Miller, C. T., \& Kaiser, C. R. (2001). A theoretical perspective on coping with stigma. Journal of Social Issues, 57(1), 73-92. http://doi.org/10.1111/0022-4537.00202

Miller, C. T., Rothblum, E. D., Felicio, D., \& Brand, P. (1995). Compensating for stigma: Obese and nonobese women's reactions to being visible. Personaliity and Social Psychology Bulletin, 21(10), 1093-1106.

Oyserman, D., \& Sakamoto, I. (1997). Being Asian American: Identity, cultural constructs, and stereotype perception. Journal of Applied Behavioral Science, 33(4), 345-453.

Packer, J. (1989). The role of stigmatization in fat people's avoidance of physical exercise. In L. Brown \& E. Rothblum (Eds.), Fat acceptance and psychotherapy (pp. 49-63). New York, NY: Haworth Press.

Petriglieri, J. L. (2011). Under threat: Responses and consequences of threats to individuals' identities. Academy of Management Review, 36(4), 641-662.

Pettigrew, T. F., \& Tropp, L. R. (2006). A meta-analytic test of intergroup contact theory. Journal of Personality and Social Psychology, 90(5), 751-783. http://doi.org/10.1037/00223514.90.5.751

Phillips, K. W., Rothbard, N. P., \& Dumas, T. L. (2009). To disclose or not to disclose? Status distance and self-disclosure in diverse environments. Academy of Management Review, 34(4), 710-732. http://doi.org/10.5465/AMR.2009.44886051

Price, M. T. (2016). The race whisperer: Barack Obama and the political uses of race. New York, NY: New York University Press.

Puhl, R. M., \& Brownell, K. D. (2006). Confronting and coping with weigt stigma: An investigation of overweight and obese adults. Obesity, 14(10), 1802-1815.

Rabelo, V. C., \& Cortina, L. M. (2013). Two sides of the same coin: Gender harassment and heterosexist harassment in LGBTQ work lives. Law and Human Behavior, 38, 1-22.

Rios, K. (2013). Right-wing authoritarianism predicts prejudice against "homosexuals" but not "gay men and lesbians." Journal of Experimental Social Psychology, 49(6), 1177-1183. http://doi.org/10.1016/j.jesp.2013.05.013

Roberson, Q. M., Holmes IV, O., \& Perry, J. (2017). Transforming research on diversity and firm performance: A dynamic capabilities perspective. Academy of Management Annals, 11(1), 189-216. http://doi.org/10.5465/annals.2014.0019

Roberts, L. M. (2005). Changing faces: Professional image construction in diverse organizational settings. Academy of Management Review, 30(4), 685-711.

Roberts, L. M., Cha, S. E., \& Kim, S. S. (2014). Strategies for managing impressions of racial identity in the workplace. Cultural Diversity and Ethnic Minority Psychology, 20(4), 529-540. http://doi.org/org/10.1037/a0037238

Roberts, L. M., \& Creary, S. J. (2013). Navigating the self in diverse work contexts. In Q. Roberson (Ed.), Oxford handbook of diversity and work (pp. 73-97). Oxford, UK: Oxford University Press.

Roberts, L. M., Settles, I. H., \& Jellison, W. A. (2008). Predicting the 
strategic identity management of gender and race. Identity, 8(4), 269-306. http://doi.org/10.1080/15283480802365270

Romero, E. J., \& Cruthirds, K. W. (2006). Use of humor in the workplace. Academy of Management Perspectives, 20(2), 58-69. http://doi.org/10.19030/ijmis.v18i1.8340

Ruggs, E. N., Martinez, L. R., \& Hebl, M. R. (2011). How individuals and organizations can reduce interpersonal discrimination. Social and Personality Psychology Compass, 5(1), 29-42. http://doi.org/10.1111/j.1751-9004.2010.00332.x

Saguy, T., Tausch, N., Dovidio, J. F., \& Pratto, F. (2009). The irony of harmony. Psychological Science, 20(1), 114-121. http://doi. org/10.1111/j.1467-9280.2008.02261.x

Segrest Purkiss, S. L., Perrewé, P. L., Gillespie, T. L., Mayes, B. T., \& Ferris, G. R. (2006). Implicit sources of bias in employment interview judgments and decisions. Organizational Behavior and Human Decision Processes, 101(2), 152-167. http:// doi.org/10.1016/j.obhdp.2006.06.005

Shelton, J. N., Richeson, J. A., \& Salvatore, J. (2005). Expecting to be the target of prejudice: Implications for interethnic interactions. Personality and Social Psychology Bulletin, 31(9), 1189-1202. http://doi.org/10.1177/0146167205274894

Shih, M., Young, M. J., \& Bucher, A. (2013). Working to reduce the effects of discrimination: Identity management strategies in organizations. American Psychologist, 68(3), 145-157. http://doi.org/10.1037/a0032250

Sigelman, C. K., Howell, J. L., Cornell, D. P., Cutright, J. D., \& Dewey, J. C. (1991). Courtesy stigma: The social implications of associating with a gay person. Journal of Social Psychology, 131(1), 45-56.

Singletary, S. L., \& Hebl, M. R. (2009). Compensatory strategies for reducing interpersonal discrimination: The effectiveness of acknowledgments, increased positivity, and individuating information. Journal of Applied Psychology, 94(3), 797-805. http://doi.org/10.1037/a0014185

Smith, B. A., Murib, Z., Motta, M., Callaghan, T. H., \& Theys, M. (2017). "Gay" or "homosexual"? The implications of social category labels for the structure of mass attitudes. American Politics Research, 46(2), 336-372 . http://doi. org/10.1177/1532673X17706560

Smith, W. J., Harrington, K. V., \& Neck, C. P. (2000). Resolving conflict with humor in a diversity context. Journal of Managerial Psychology, 15(5), 606-621. http://doi. org/10.1108/02683940010346743

Staff Reports. (2016, April 22). How one scholar's arrest tainted the president's image as a racial healer. The Washington Post. Retrieved from https://www.washingtonpost.com/ graphics/national/obama-legacy/henry-louis-gates-jr-arrest-controversy.html

Steele, C. M. (1997). A threat in the air: How stereotypes shape intellectual identity and performance. American Psychologist, 52(6), 613-629.

Suls, J., \& Fletcher, B. (1985). The relative efficacity of avoidant and non-avoidant coping strategies. Health Psychology, 4(3), 249-288.

Swim, J. K., Aikin, K. J., Hall, W. S., \& Hunter, B. A. (1995). Sexism and racism: Old-fashioned and modern prejudices. Journal of personality and social psychology, 68(2), 199.

Swim, J. K., Ferguson, M. J., \& Hyers, L. L. (1999). Avoiding stigma by association: Subtle prejudice against lesbians in the form of social distancing. Basic and Applied Social Psychology, 21(1), 61-68. http://doi.org/10.1207/s15324834basp2101

Thernstrom, A. (2013). Obama's mistake on Trayvon Martin case. Retrieved from https://www.cnn.com/2013/07/15/opinion/ thernstrom-trayvon-martin-obama/index.html

Thomas, D. A. (1993). Racial dynamics in cross-race developmental relationships. Administrative Science Quarterly, 38, 169-194. http://doi.org/10.2307/2393410

Trawalter, S., Adam, E. K., Chase-Lansdale, P. L., \& Richeson, J. A. (2012). Concerns about appearing prejudiced get under the skin: Stress responses to interracial contact in the moment and across time. Journal of Experimental Social Psychology, 48(3), 682-693. http://doi.org/10.1016/j.jesp.2011.12.003

U.S. Equal Employment Opportunity Commision. (2017). No titlecharge statistics (Charges filed with EEOC) FY 1997 Through FY2017. Retrieved April 5, 2018, from https://www. eeoc.gov/eeoc/statistics/enforcement/charges.cfm

Vakoch, D. A., \& Wurm, L. H. (1997). Emotinal connotation in speech perception: Semantic associations in the general lexicon. Cognition and Emotion, 11, 337-349.

Whitson, J., Wang, C. S., Kim, J., Cao, J., \& Scrimpshire, A. (2015). Responses to normative and norm-violating behavior: Culture, job mobility, and social inclusion and exclusion. Organizational Behavior and Human Decision Processes, 129, 24-35. http://doi.org/10.1016/j.obhdp.2014.08.001

Willard, M. (2010). Homo-humor: Laughter as a protective factor in the face of homophobia and heterosexism. San Diego, CA: Alliant International University.

Wurm, L. H., \& Vakoch, D. A. (1996). Dimensions of speech perception: Semantic associations in the affective lexicon. Cognition and Emotion, 10(4), 409-424. http://doi. org/10.1080/026999396380204

Wyatt, M., \& Silvester, J. (2015). Reflections on the labyrinth: Investigating black and minority ethnic leaders' career experiences. Human Relations, 68(8), 1243-1269. http://doi. org/10.1177/0018726714550890

RECEIVED 05/14/18 ACCEPTED 04/24/19 